\title{
Geography Teachers' Attitudes and Beliefs Regarding Classroom Management
}

\author{
Yurdal Dikmenli ${ }^{1} \&$ Taner Çif̧̧i $^{2}$ \\ ${ }^{1}$ Assist. Prof. Dr., Ahi Evran University, Faculty of Education Primary Education, Turkey \\ ${ }^{2}$ Assist. Prof. Dr., Cumhuriyet University, Faculty of Education Primary Education, Turkey \\ Correspondence: Taner Çifçi, Assist. Prof. Dr., Cumhuriyet University, Faculty of Education Primary Education, \\ Turkey
}

Received: April 9, 2016

Accepted: April 21, 2016

Online Published: April 22, 2016

doi:10.5430/ijhe.v5n2p283

URL: http://dx.doi.org/10.5430/ijhe.v5n2p283

\begin{abstract}
This study scrutinizes geography teachers' attitude and belief levels regarding classroom management. As a matter of fact, classroom management is one of the prominent areas emphasized by all educators. Descriptive correlational survey model was used in the study. Study group includes 58 geography teachers working in Sivas province during the 2015-2016 academic year. Convenience sampling method was employed while forming the study group. The Attitudes \& Beliefs on Classroom Control Inventory developed by Martin, Yin \& Baldwin (1998) and adapted into Turkish language by Sarvan (2002) was employed to collect the data. The statistical analyses were carried out using SPSS 17. To analyze the relationships between the variables, t-test for independent samples, Mann Whitney-U test, and Pearson's correlation were used. Significance level was set to be $\mathrm{p}<.05$. Geography teachers' mean scores for the sub-dimensions of instructional management and people management and their mean total scores for classroom management attitude and belief corresponded to medium level (interactionalist classroom management). Their mean scores for the sub-dimension of behavior management corresponded to low level (non-interventionist classroom management). No significant difference was found between the geography teachers' mean scores for the sub-dimensions of instructional management, people management, and behavior management and total scores for classroom management attitude and belief by gender and the type of the high school they work in. In addition, no significant relationship was found between years in teaching and instructional management. However, a negative significant relationship was detected between teachers' years in teaching and people management, behavior management, and classroom management attitude and belief. It is recommended that arrangements and studies be made for teachers to develop attitudes and beliefs that will allow their students to know themselves, make decisions, and carry out tasks either individually or in group.
\end{abstract}

Keywords: Geography, Geography teacher, Classroom management, Attitude and belief

\section{Introduction}

Classroom management is one of the areas whose importance is emphasized by all educators (Baumert \& Kunter, 2013; Long \& Frye, 1989; Weinstein, 1996; Weinstein \& Mignano, 1993). This is because a lot of different factors and participants come together in the classroom, including teacher, student, parent, curriculum, school administration, other staff of school, beliefs and values, capital, government policy. Classrooms are the most important learning environments where teachers and students interact with one another. Teachers' attitudes, beliefs, and behaviors may influence classroom climate negatively in these complex and demanding environments (Ming-tok \& Wai-shing, 2008). Though teachers play various roles in classes, one of the most important ones is classroom management (Evertson \& Weinstein, 2006; Marzano, Marzano \& Pickering, 2003).

Snyder (1998) defines classroom management as the type of management involving activities that encourage learning, reflect student-teacher interactions, provide effects that introduce educational awareness, and activate all the physical environment of the class. A positive teacher-student relationship can be achieved through a perfect preparation and organization, clearly set expectations, procedures, and results, and an effective classroom management in a good classroom (Hargrove, 2008). However, a good classroom management starts with positive relations between teachers and students (Heller, 2002). Positive relations are established more easily between students and teachers who support students' self-confidence in the class, inspire them, increase student participation, 
include them in critical thinking processes, improve satisfaction, success, motivation, and social relations, prevent or lessen dropout, and minimize disruptive behaviors (Walker, 2009). In this sense, teachers can be considered sources of external motivation influential on students (Mader, 2009).

An effective geography instruction requires teachers to improve students' individual and group characteristics according to the knowledge, skills, and values embedded within acquisitions. In addition, they bring together a lot of components by drawing various shapes over students' skills and personalities like a painter. Then teachers can adapt their students to unique environmental conditions in the classroom ecosystem (Zabel \& Zabel, 1996). In this sense, geography teachers provide the conditions that prepare their students for life (Levin \& Nolan, 2000).

According to the previous studies, teachers' attitudes, beliefs, and practices regarding classroom management influence their academic expectations and success (Martin \&Baldwin, 1992; Pajares, 1992; Taddeo, 1977). Eventually, teachers with positive attitudes and beliefs spend more effort for their students. Such teachers can motivate their students for learning better and are enthusiastic. They can struggle with failure. They can be more tolerant towards their students. They are open to innovations and changes and they build relationships based on trust (Bandura, 2001; Brouwers \& Tomic, 2000; Gibbs, 2002; Woolfolk Hoy, Hoy \& Kurz, 2008; Woolfolk \& Hoy, 1990).

This study dwells on geography teachers' attitude and belief levels regarding classroom management. This is considered important because there is a need to reveal geography teachers' attitudes and beliefs regarding classroom management and raise an awareness for an efficient geography education. The limited amount of studies in this matter in the geography literature increases the importance of the study. It is also believed that this study may be a reference to future studies, which will increase its contribution to the scientific world.

\subsection{Problem Statement}

The main research question of the study is as follows: "Is there a significant difference between geography teachers' attitude and belief levels regarding classroom management by various variables (gender, the type of high school they work in, and years in teaching)?"

\section{Method}

\subsection{Research Model}

Descriptive correlational survey model was used in the study. Convenient sampling method was used as reaching geography teachers who were studying near by the researchers was cost effective and time saving. In this sense, geography teachers' attitude and belief levels regarding classroom management were tried to be revealed by various variables. Survey model is an approach aiming to describe a situation in the past or present as the way it is/was. Correlational survey refers to models revealing whether there is a difference between two or more variables or the degree of difference, if any (Karasar, 2012).

\subsection{Study Group}

The study group of this research includes 58 geography teachers working in Sivas province during the 2015-2016 academic year. Convenience sampling method was employed to form the study group. Table 1 shows the study group's distribution according to gender, years in teaching, and the type of high school teachers work in.

Table 1. The distribution of the study group according to gender, years in teaching, and the type of high school they work in

\begin{tabular}{|c|c|c|c|}
\hline Variables & & $\mathbf{f}$ & $\%$ \\
\hline \multirow{2}{*}{ Gender } & Female & 28 & 48.3 \\
\hline & Male & 30 & 51.7 \\
\hline \multirow{2}{*}{$\begin{array}{l}\text { The type of high } \\
\text { school }\end{array}$} & Science High School & 7 & 12.1 \\
\hline & Anatolian High School & 51 & 87,9 \\
\hline Total & & 58 & 100 \\
\hline \multirow{2}{*}{$\begin{array}{l}\text { Years } \\
\text { teaching }\end{array}$} & Minimum & Mean & $\begin{array}{l}\text { Standard } \\
\text { Deviation }\end{array}$ \\
\hline & 25 & 10.98 & 4.96 \\
\hline
\end{tabular}

The demographic data of the study group cover gender, the types of the high schools teachers work in, and years in teaching. Table 1 shows that $48.3 \%$ (28) of the participating teachers are female while $51.7 \%$ (30) are male. 12.1\% (7) 
of the teachers work in science high schools while $87.9 \%$ work in Anatolian high schools. Such distribution stems from the distribution of high schools across the province (i.e. most are Anatolian high schools). Years in teaching show that minimum period of experience is 3 years while maximum period of experience is 25 years. The average experience in teaching is 11 years.

\subsection{Data Collection Tool}

"Attitudes \& Beliefs on Classroom Control Inventory" developed by Martin, Yin \& Baldwain (1998) and adapted into Turkish language by Sarvan (2002) was employed to collect the data necessary for the study. The inventory has 26 items and 3 sub-dimensions. It is a four-point Likert-type inventory with a rating from 1 to 4 . The rating is as follows: “(1) I definitely disagree", “(2) I disagree”, “(3) I agree”, and "(4) I definitely agree”. The inventory has three sub-dimensions which are instructional management (14 items), people management (8 items), and behavior management (4 items). Based on the responses of the study group to the inventory items, Cronbach's alpha reliability coefficient was found to be .741. Accordingly, it is possible to say that the inventory yields quite reliable results (Can, 2013).

\subsection{Data Analysis}

There are 14 positive and 12 negative items in the inventory aimed at revealing the attitude and belief levels of geography teachers regarding classroom management. Negative items were reversely coded and graded. Accordingly, the lowest score to be obtained from the inventory is 26 while the highest one is 104 . The statistical analyses of the study were made using SPSS 17. In this sense, the attitude and belief levels of the teachers regarding classroom management were determined via percentages, frequencies, arithmetic means, and standard deviations. Categorization of the scores derived from Attitudes \& Beliefs on Classroom Control Inventory was based on the manual of the scale (Martin, Yin \& Baldwain, 1998). The results regarding the teachers' attitude and belief levels were grouped as follows: the scores between 26 and 51.9 correspond to low level (non-interventionist classroom management); the scores between 52 and 77.9 correspond to medium level (interactionalist classroom management); and the scores between 78 to 104 correspond to high level (interventionist classroom management). Table 2 shows the minimum and maximum scores that were used to determine the sub-dimensions of the geography teachers' attitude and belief levels regarding classroom management as well as the score ranges corresponding to the sub-dimensions of the inventory. T-test for independent samples, Mann Whitney-U test, and Pearson's correlation test were employed to analyze the relationships between the variables. The significance level was set to be $\mathrm{p}<.05$.

Table 2. The minimum and maximum scores used to determine the sub-dimensions of the geography teachers' attitude and belief levels regarding classroom management as well as the score ranges corresponding to the sub-dimensions of the inventory

\begin{tabular}{|c|c|c|c|c|c|}
\hline Sub-dimension & $\begin{array}{l}\text { The number } \\
\text { of items }\end{array}$ & $\begin{array}{l}\text { Minimum } \\
\text { score }\end{array}$ & $\begin{array}{l}\text { Maximum } \\
\text { score }\end{array}$ & Level & Score range \\
\hline \multirow{3}{*}{$\begin{array}{l}\text { Instructional } \\
\text { Management }\end{array}$} & \multirow{3}{*}{14} & \multirow{3}{*}{14} & \multirow{3}{*}{66} & Low & $14-31.3$ \\
\hline & & & & Medium & $31.4-48.7$ \\
\hline & & & & High & $48.8-66$ \\
\hline \multirow{3}{*}{$\begin{array}{l}\text { People } \\
\text { Management }\end{array}$} & \multirow{3}{*}{8} & \multirow{3}{*}{8} & \multirow{3}{*}{32} & Low & $8-15.9$ \\
\hline & & & & Medium & $16-23.9$ \\
\hline & & & & High & $24-32$ \\
\hline \multirow{3}{*}{$\begin{array}{l}\text { Behavior } \\
\text { Management }\end{array}$} & \multirow{3}{*}{4} & \multirow{3}{*}{4} & \multirow{3}{*}{16} & Low & $4-7.9$ \\
\hline & & & & Medium & $8-11.9$ \\
\hline & & & & High & $12-16$ \\
\hline \multirow{3}{*}{ Total } & \multirow{3}{*}{26} & \multirow{3}{*}{26} & \multirow{3}{*}{104} & Low & $26-51.9$ \\
\hline & & & & Medium & $52-77.9$ \\
\hline & & & & High & 78-104 \\
\hline
\end{tabular}

\section{Findings and Their Interpretations}

\subsection{The Geography Teachers'Attitude and Belief Levels Regarding Classroom Management}

Table 3 shows the geography teachers' total scores for attitude and belief levels regarding classroom management as well as their scores for sub-dimensions. 
Table 3. The geography teachers' attitude and belief levels regarding classroom management

\begin{tabular}{lllll}
\hline Sub-Dimensions & Minimum & Maximum & Average & $\begin{array}{l}\text { Standard } \\
\text { Deviation }\end{array}$ \\
\hline $\begin{array}{l}\text { Instructional } \\
\text { Management }\end{array}$ & 29.00 & 53.00 & 43.82 & 4.76 \\
People Management & 9.00 & 24.00 & 16.13 & 2.95 \\
Behavior Management & 4.00 & 14.00 & 7.46 & 1.81 \\
\hline Total & 50.00 & 79.00 & 67.43 & 5.64
\end{tabular}

As table 3 shows, teachers' mean scores for the behavior sub-dimension are low $(X=7.46, S D=1.81)$. Their mean scores for instructional management $(X=43.82, S D=4.76)$ and people management $(X=16.13, S D=2.95)$ are at medium levels. Their mean total scores regarding the inventory $(X=67.43, S D=5.64)$ are at low level as well.

\subsection{The Geography Teachers'Attitude and Belief Levels Regarding Classroom Management by Gender}

Table 4 shows the results of the independent t-test that was conducted to see if there is a significant difference between the geography teachers' inventory scores in the instructional management and people management sub-dimensions by gender.

Table 4. T-test results concerning the geography teachers' inventory scores regarding the sub-dimensions of instructional management and people management by gender

\begin{tabular}{llllllll}
\hline Sub-Dimensions & Gender & N & Means & $\begin{array}{l}\text { Standard } \\
\text { Deviation }\end{array}$ & t & sd & p \\
\hline Instructional & Female & 28 & 43.14 & 5.89 & -1.05 & 56 & .295 \\
Management & Male & 30 & 44.46 & 3.39 & & & \multirow{2}{*}{56} \\
\hline People & Female & 28 & 16.07 & 3.21 & -.164 & 56 & .870 \\
\hline
\end{tabular}

As it is seen from Table 4, the arithmetic means of geography teachers' scores regarding the instructional management [ $\mathrm{t}(56)=.295, \mathrm{p}>.05]$ and people management $[\mathrm{t}(56)=.870, \mathrm{p}>.05]$ sub-dimensions do not differ by gender. Accordingly, it is possible to say that male and female teachers have equal attitude and belief levels regarding instructional management and people management.

Table 5 below presents the results of the independent groups Mann Whitney-U test, which was conducted to see if there is a significant difference between the geography teachers' inventory scores for the behavior management sub-dimension and the overall classroom management by gender.

Table 5. Mann Whitney-U test results concerning the geography teachers' attitude and belief levels regarding behavior management and classroom management by gender

\begin{tabular}{lllllll}
\hline Sub-Dimensions & Gender & $\mathbf{N}$ & Mean rank & Sum Rank & $\begin{array}{l}\text { Mann } \\
\text { Whitney U }\end{array}$ & p \\
\hline Behavior & Female & 28 & 32.91 & 921.50 & 324.500 & .128 \\
Management & Male & 30 & 26.32 & 789.50 & & \\
\hline Total & Female & 28 & 29.59 & 828.50 & & \\
& Male & 30 & 29.42 & 882.50 & 417.500 & .969 \\
& Total & 58 & & & & \\
\hline
\end{tabular}

As seen in table 5, geography teachers' behavior management [U=324.50, $\mathrm{p}>.05]$ sub-dimension scores and total classroom management scores $[\mathrm{U}=417.50, \mathrm{p}>.05]$ do not significantly differ by gender. Accordingly, it is possible to say that female and male teachers have equal attitude and belief levels regarding behavior management and classroom management. 
3.3 The Geography Teachers' Attitude and Belief Levels Regarding Classroom Management According to the Type of the High School They Work in

Table 6 shows the results of the independent samples t-test that was conducted to see if there is a significant difference between the geography teachers' instructional management and people management sub-dimension scores according to the type of the high school they work in.

Table 6. T-test results concerning the geography teachers' instructional management and people management sub-dimension scores according to the type of the high school they work in

\begin{tabular}{llllllll}
\hline Sub-Dimensions & The Type of High School & $\mathbf{N}$ & Means & $\begin{array}{l}\text { Standard } \\
\text { Deviation }\end{array}$ & $\mathbf{t}$ & sd & p \\
\hline Instructional & Science High Schools & 7 & 42.00 & 7.25 & -1.083 & 56 & .283 \\
Management & Anatolian High Schools & 51 & 44.07 & 4.36 & & & \\
\hline People & Science High Schools & 7 & 15.14 & 3.43 & -.950 & 56 & .346 \\
Management & Anatolian High Schools & 51 & 16.27 & 2,89 & & &
\end{tabular}

As seen from table 4, geography teachers' instructional management [t(56) $=-1.083, \mathrm{p}>.05]$ and people management $[\mathrm{t}(56)=-950, \mathrm{p}>.05]$ sub-dimension mean scores do not significantly differ according to the type of the high school they work in. Accordingly, it is possible to say that the teachers have equal attitude and belief levels regarding instructional management and people management regardless of the high school they work in.

Table 7 below shows the results of the independent groups Mann Whitney-U test that was conducted to see if there is a significant difference between the geography teachers' inventory scores for the behavior management sub-dimension and the overall classroom management according to the type of the high school they work in.

Table 7. Mann Whitney-U test results concerning the geography teachers' attitude and belief levels regarding behavior management and classroom management according to the type of high school they work in

\begin{tabular}{|c|c|c|c|c|c|c|}
\hline Sub-Dimensions & $\begin{array}{l}\text { The Type of } \\
\text { High School }\end{array}$ & $\mathbf{N}$ & Mean Rank & Sum Rank & $\begin{array}{c}\text { Mann } \\
\text { Whitney U }\end{array}$ & $\mathbf{p}$ \\
\hline \multirow{3}{*}{$\begin{array}{l}\text { Behavior } \\
\text { Management }\end{array}$} & Science & 7 & 21.36 & 149.50 & 121.500 & .163 \\
\hline & $\begin{array}{l}\text { High } \\
\text { Schools }\end{array}$ & & & & & \\
\hline & $\begin{array}{l}\text { Anatolian } \\
\text { High } \\
\text { Schools }\end{array}$ & 51 & 30.62 & 1561.50 & & \\
\hline \multirow[t]{2}{*}{ Total } & $\begin{array}{l}\text { Science } \\
\text { High } \\
\text { Schools }\end{array}$ & 7 & 24.14 & 169.00 & 141.000 & .369 \\
\hline & $\begin{array}{l}\text { Anatolian } \\
\text { High } \\
\text { Schools }\end{array}$ & 51 & 30.24 & 1542.00 & & \\
\hline
\end{tabular}

As it is clear from table 7, geography teachers' behavior management [U=121.50, $\mathrm{p}>.05]$ sub-dimension scores and total classroom management scores [U=141.00, $\mathrm{p}>.05]$ do not differ according to the type of the high school they work in. Accordingly, it is possible to say that teachers have equal attitude and belief levels regarding behavior management and classroom management regardless of the type of the high school they work in.

3.4 The Geography Teachers' Attitude and Belief Levels Regarding Classroom Management According to Years in Teaching

Table 8 shows the results of the independent groups Pearson's correlation test that was conducted to see if there is a significant relationship between the geography teachers' inventory scores regarding classroom management and their years in teaching. 
Table 8. The Pearson's correlation test results regarding the geography teachers' classroom management attitude and belief levels according to years in teaching

\begin{tabular}{llllll}
\hline & & $\begin{array}{l}\text { Instructional } \\
\text { Management }\end{array}$ & $\begin{array}{l}\text { People } \\
\text { Management }\end{array}$ & $\begin{array}{l}\text { Behavior } \\
\text { Management }\end{array}$ & Total \\
\hline Years in & Pearson's Correlation & -.041 & $-.277^{*}$ & $-.262^{*}$ & $-.264^{*}$ \\
Teaching & $\mathrm{P}$ & .760 & .035 & .047 & .045 \\
& $\mathrm{~N}$ & & & & 58
\end{tabular}

As can be seen from table 8, Pearson's correlation test results show that there is no significant relationship between the teachers' years in teaching and their attitude and belief levels regarding instructional management $(\mathrm{r}=-.041$, $\mathrm{p}>0.05$ ). However, negative relationships were detected between the teachers' years in teaching and their attitude and belief levels regarding people management $(r=-.277, p<0.05)$, behavior management $(r=-.262, p<0.05)$, and classroom management $(r=-.264, p<0.05)$. Thus, it is possible to say that as years in teaching increase, a decrease occurs in attitude and belief levels regarding people management, behavior management, and classroom management.

\section{Conclusion and Discussion}

This study is an attempt to analyze geography teachers' attitude and belief levels regarding classroom management based on various variables. The results obtained in the study produced to the conclusions below.

Geography teachers' instructional management and people management mean scores and classroom management mean total scores correspond to medium level (interactionalist classroom management). Their behavior management sub-dimension mean scores correspond to low level (non-interventionist classroom management). When the responsibility of schools on creating and practicing a democratic culture is taken into consideration, the existence of interactionist attitude of teachers and students towards people and behavior management can be considered as positive for classroom management (Büyükkaragöz \& Çivi, 1999; Schlechty, 2005). In addition, healthy communication and interaction between teachers and students make positive contributions to student development, class participation, and academic achievement (Baker, 2006; Claus \& Booth-Butterfield and Chory, 2012; Koepke \& Harkins, 2008). Similarly, Taddeo (1977) conducted a study scrutinizing the influence of teachers' attitudes and beliefs on students' learning levels. He revealed that teachers' attitudes and beliefs are among the factors which have utmost importance in terms of such influence.

It was found that geography teachers' instructional management, people management, and behavior management mean scores as well as classroom management mean total scores do not differ by gender. Accordingly, it is possible to say that female and male teachers have close scores to each other in both overall classroom management and its sub-dimensions. Previous studies on classroom management emphasize that gender is an important variable creating difference (Amin, 1994; Ekici, 2008; Erol, 2006; Grossmann, 1990; Güvenç, 2012; İlgar, 2007; Martin \& Yin, 1997; Özgan et al., 2011; Parsons, 1982; Savran \& Çakıroğlu, 2004; Van Oostendorp, 1991; Zeremba \& Fluck, 1995). However, our results indicated that there is no statistical difference between the teachers' attitude and belief levels regarding classroom management and its sub-dimensions by gender (Ekici, 2008; Ekici et al., 2012; Denkdemir, 2007; Okut, 2011; Savran Gencer \& Çakıroğlu, 2007).

It was determined that there is no significant difference between the geography teachers' scores from instructional management, people management, and behavior management sub-dimensions and their classroom management mean total scores according to the type of the high school they work in. Accordingly, it is possible to say that geography teachers have close attitude and belief levels regarding the overall classroom management and its sub-dimensions regardless of the type of the high school they work in. No comparison can be made with previous studies here as there are not adequate studies concentrating on this issue that have been conducted before.

It was detected that there is no significant relationship between the geography teachers' years in teaching and their attitude and belief levels regarding instructional management. However, negative significant relationships were detected between their years in teaching and their attitude and belief levels regarding people management, behavior management, and classroom management. As years in teaching increase, a fall occurs in the teachers' attitude and belief levels regarding people management, behavior management, and classroom management. Ekici et al. (2012) state that biology teachers have higher classroom management scores as their years in service increase. They also mention that these groups of teachers have the most authoritative (interventionist) classroom management profile. Foxworthy (2006) conducted a study titled "Teachers' beliefs about classroom management" and emphasized that 
teachers develop positive attitudes and beliefs as of their first day in teaching and go through some changes in classroom management strategies. A similar result was obtained by Soltay (2007) working on English teachers. The results of the present study are inconsistent with the results of these studies. Differences between the results may stem from differences between fields of teachers. The results of the present study imply that as years in teaching increase, a fall occurs in attitude and belief levels regarding classroom management (i.e. teachers stay away from the interventionist type of classroom management). This may be because teachers get more mature, have more experience, and do not need an authoritative management anymore. Ünal \& Ünal (2012) pointed that beginning teachers prefer to be mostly in control and make the rules themselves. Beginning teachers' knowledge of classroom management is essential (Gold \& Holodynski, 2015), because it is a necessity for development of interactionist attitude. It is possible to say that young teachers with a shorter period of experience in teaching may prefer to keep an authoritarian style since they are not experienced enough.

\section{Recommendations}

By increasing the class hours of applied courses in education faculties, pre-service teachers may be equipped with a democratic sense of classroom management.

Young teachers can be given seminars on classroom management and control in order to equip them with student-centered teaching methods and techniques as pointed by recent curricula.

In education faculties, new people and behavior management practices may be offered within educational psychology and sociology field to make pre-service teachers turn their internationalists attitudes into behaviors.

More in-service training activities may be organized in regard to the teaching models marked by the current trends in the changed curricula.

The reasons underlying the teachers' attitude and belief levels regarding classroom management can be analyzed, and permanent solutions can be suggested if there are any problems.

Certain arrangements and studies can be made to make teachers develop attitudes and beliefs that allow students to know themselves, make decisions, and perform tasks either individually or in groups.

\section{References}

Amin, M. E. (1994). Gender as a discriminating factor in the evaluation of teaching. Assessment \& Evaluation in Higher Education, 19(2), 135-143. http://dx.doi.org/10.1080/0260293940190206

Baker, J. A. (2006). Contributions of teacher-child relationships to positive school adjustment during elementary school. Journal of School Psychology, 44, 211-229. http://dx.doi.org/10.1016/j.jsp.2006.02.002

Bandura, A. (2001). Guide for constructing self-efficacy scales (Monograph). Stanford, CA: Stanford University.

Baumert, J., \& Kunter, M. (2013). The COACTIV model of teachers' professional competence. In M. Kunter, J. Baumert, W. Blum, U. Klusmann, S. Krauss, \& M. Neubrand (Eds.), Cognitive activation in the mathematics classroom and professional competence of teachers. Results from the COACTIV project (pp. 25-48). New York, NY: Springer. http://dx.doi.org/10.1007/978-1-4614-5149-5_2

Brouwers, A., \& Tomic, W. (2000). A longitudinal study of teacher burn out and perceived self-efficacy in classroom management. Teaching and Teacher Education, 16, 239-253. http://dx.doi.org/10.1016/S0742-051X(99)00057-8

Büyükkaragöz, S. \& Çivi, C. (1999). Genel öğretim metotları (10. Baskl). İstanbul: Beta Yayım Dağıtım.

Can, A. (2013). SPSS ile Bilimsel Araştırma Sürecinde Nicel Veri Analizi. Pegem Akademi Yayınları, Ankara.

Claus, C. J., Booth-Butterfield, M., \& Chory, R. M. (2012). The relationship between instructor misbehaviors and student antisocial behavioral alteration techniques: The roles of instructor attractiveness, humor, and relational closeness. Communication Education, 61(2), 161-183. http://dx.doi.org/10.1080/03634523.2011.647922

Denkdemir, E. (2007). Sınıf Öğretmenlerinin Sınıf Yönetimi Hakkında Görüşleri ve Bir Uygulama. Yayımlanmamış Yüksek Lisans Tezi, Beykent Üniversitesi, Sosyal Bilimler Enstitüsü, İstanbul.

İlgar, L. (2007). İlköğretim Öğretmenlerinin Sınıf Yönetimi Anlayışı Üzerine Bir Araştırma. Yayımlanmamış Yüksek Lisans Tezi, İstanbul Üniversitesi Sosyal Bilimler Enstitüsü, İstanbul.

Ekici, G. (2008). Sınıf Yönetimi Dersinin Öğretmen Adaylarının Sınıf Yönetimine Yönelik Tutum ve İnanç Kazanma Düzeyine Etkisi. Çukurova Üniversitesi Sosyal Bilimler Enstitüsü Dergisi, 17(3), 167-182. 
Ekici, G., Aluçdibi, F., \& Öztürk, N. (2012). Biyoloji öğretmenlerinin sınıf yönetimi profillerinin cinsiyet ve kıdem değiş̧kenleri açısından incelenmesi, Dicle Üniversitesi Sosyal Bilimler Enstitüsü Dergisi, Yı1:4, 8,13-30.

Erol, Z. (2006). Sınıf Öğretmenlerinin Sınıf Yönetimi Uygulamalarına İlişkin Görüşleri. Yayımlanmamış Yüksek Lisans Tezi, Afyon Kocatepe Üniversitesi, Sosyal Bilimler Enstitüsü, Afyon.

Evertson, C. M., \& Weinstein, C. S. (2006). Classroom management as a field of inquiry. In C. M. Evertson \& C. S. Weinstein (Eds.), Handbook of classroom management: Research, practice, and contemporary issues (pp. 3-16). Mahwah, NJ: Lawrence Erlbaum Associates.

Foxworthy, J. E. (2006). Teachers' Beliefs about classroom management, Thesis (MSc), Lakehead University.

Gibbs, C. (2002). Effective teaching: Exercising self-efficacy and thought control of action [online], Annual Conference of the British Educational Research Association, 12-14 September 2002 England, Education-linedatabase, Retrieved from: http://www.leeds.ac.uk/educol/documents/00002390.htm

Gold, B., \& Holodynski, M. (2015). Development and Construct Validation of a Situational Judgment Test of Strategic Knowledge of Classroom Management in Elementary Schools. Educational Assessment, 20(3), 226-248. http://dx.doi.org/10.1080/10627197.2015.1062087

Grossmann, H. (1990). Trouble-free teaching: Solutions to behavior problems in the classroom. Toronto: Mayfield Publishing.

Güvenç, E. (2012). Sınıf Öğretmenlerinin Sınıf Yönetim Biçemleri ve Denetim Odakları. Buca Eğitim Fakültesi Dergisi, 33,64-80.

Hargrove, P. C. (2008). An investigation of the life experiences and beliefs of teachers exhibiting effective classroom management behaviors in diverse urban schools (Order No. 3415936). Available From ProQuest Education Journals. (734624618). Retrieved from: http://search.proquest.com/docview/734624618?accountid=14068

Heller, D. (2002). The power of gentleness. Educational Leadership, 59(8), 76-79.

Karasar, N. (2012). Bilimsel Araştırma Yöntemi. 24. Baskı, Nobel Yayınları No: 58, Ankara

Koepke, M. F., \& Harkins, D. A. (2008). Conflict in the classroom: Gender differences in the teacher-child relationship. Early Education \& Development, 19(6), 843-864. http://dx.doi.org/10.1080/10409280802516108

Levin, J. \& Nolan, J. F. (2000). Principles of Classroom Management: A Professional Decision Making Model. USA: Allyn \& Bacon.

Long, J. D. \& Frye, V. H. (1989). Making it till Friday, 4th ed. Princeton, NJ: Princeton Book Company, Inc.

Mader, C. E. (2009). I will never teach the old way again: Classroom management and external incentives. Theory Into Practice, 48(2), 147-155. http://dx.doi.org/10.1080/00405840902776483

Martin, N. K., \& Baldwin, B. (1992, November). Beliefs regarding classroom management style: The differences between pre-service and experienced teachers. Paper presented at the annual meeting of the Mid-South Educational Research Association. Knoxville, T.N. (ERIC Document Reproduction Service No. ED 355 213).

Martin, N. K., \& Yin, Z. (1997). Attitudes and beliefs regarding classroom management style: Differences between male \& female teachers. Paper presented at the annual meeting of the Southwest Educational Research Association, Austin, TX. (ERIC Document Reproduction Service No. ED 404 708).

Martin, N. K., Yin, Z., \& Baldwin, B. (1998). Construct validation of the attitudes and beliefs on classroom control inventory. Journal of Classroom Interaction, 33(2), 6-15.

Marzano, R. J., Marzano, J. S., \& Pickering, D. J. (2003). Getting Off to a Good Start. In R. J. Marzano, J. S. Marzano, \& D. J. Pickering, Classroom management that works: Researched-based strategies for every teacher (pp. 92-102). Alexandria, VA: Association for Supervision and Curriculum Development.

Ming-tok, H. \& Wai-shing, L. (2008). Classroom Management Creating A Positive Learning Environment. Hong Kong: Hong Kong University Press, 2-5. http://dx.doi.org/10.5790/hongkong/9789622098886.001.0001

Okut, L. (2011). İlköğretim Fen ve Teknoloji, Matematik Öğretmenlerinin Eğitime ve Sınıf Yönetimine İlişkin İnançları Arasındaki İlişki. Pegem Eğitim ve Öğretim Dergisi, 1(4), 39-51.

Özgan, H., Yiğit, C., Aydın, Z \& Küllük M. C. (2011). İlköğretim Okulu Öğretmenlerinin Sınıf Yönetimine İlişkin Algılarının İncelenmesi ve Karşılaştırılması. Gaziantep Üniversitesi Sosyal Bilimler Dergisi, 10(1), 617- 635 
Pajares, F. (1992). Teachers' and beliefs educational research: Cleaning up messy construct. Review of Educational Research. 62 (3), 307-332. http://dx.doi.org/10.3102/00346543062003307

Parsons, J. E. (1982). Sex differences in attributions and learned helplessness. Sex Roles, 8(4), 421-432. http://dx.doi.org/10.1007/BF00287281

Savran, A. (2002). Pre-service science teachers' efficacy beliefs regarding science teaching and their classroom management beliefs (Yayımlanmamış yüksek lisans tezi). Ortadoğu Teknik Üniversitesi, Sosyal Bilimler Enstitüsü, Ankara

Savran, A., \& Çakiroğlu, J. (2004). Preservice Science Teachers' Orientations to Classroom Management. Hacettepe Üniversitesi Eğitim Fakültesi Dergisi, 26,124-134.

Savran Gencer, A. \& Çakiroğlu, J. (2007). Turkish pre-service science teachers' efficacy beliefs regarding science teaching and their beliefs about classroom management. Teaching and Teacher Education, 23, 664-675. http://dx.doi.org/10.1016/j.tate.2005.09.013

Schlechty, C. P. (2005). Okulu yeniden kurmak. (Çev. Y.Özden). Ankara: Nobel Yayınları.

Snyder, D. (1998). Classroom management for student teachers. Music Educators Journal, 84(4), 37. http://dx.doi.org/10.2307/3399115

Soltay, E. Ö. (2007). İngilizce öğretmenliği son sınıf stajını yapan öğretmen adaylarının, az deneyimli ve deneyimli İngilizce öğretmenlerinin sınıf yönetimi konusunda karar verme becerileri, Yüksek lisans tezi, Marmara Üniversitesi Eğitim Bilimleri Enstitüsü.

Taddeo, I. S. (1977, February). Do teachers' attitudes effect learning? National Association of Secondary School Principals Bulletin, 67(406), 7-13.

Ünal, Z., \& Ünal, A. (2012). The impact of years of teaching experience on the classroom management approaches of elementary school teachers. International journal of Instruction, 5(2), 41-60.

Van Oostendorp, K. (1991) Effect of Student Gender Bias toward the Instructor on Classroom Management at the Secondary Level. Masters Dissertation, Siena Heights College, Siena. (Eric Document Reproduction Service No: ED 346 191).

Walker, J. T. (2009). Authoritative classroom management: How control and nurturance work together. Theory Into Practice, 48(2), 122-129. http://dx.doi.org/10.1080/00405840902776392

Weinstein, C. S. (1996). Secondary classroom management: Lesson from research and practice. New York: McGraw-Hill.

Weinstein, C. S. \& A. J. Mignano, Jr. (1993). Elementary classroom management: Lessons from research and practice. New York: McGraw-Hill.

Woolfolk, A. E. \& Hoy, W. K. (1990). Prospective teachers' sense of efficacy and beliefs about control. Journal of Educational Psychology, 82(1), 81-91. http://dx.doi.org/10.1037/0022-0663.82.1.81

Woolfolk Hoy, A., W.K. Hoy, \& N.M. Kurz. (2008). Teacher's academic optimism: The development and test of a new construct. Teaching and Teacher Education 24, 821-35. http://dx.doi.org/10.1016/j.tate.2007.08.004

Zabel, R. H., \& Zabel, M. K. (1996). Classroom management in Context: Orchestrating Positive Learning Environments. Boston, MA: Houghton Mifflin.

Zeremba, S. B. \& Fluck, S. E. (1995). Gender and patterns of communication. Proceedings of the 9th Annual Conference in Under graduate Teaching of Psychology (Eric Document Reproduction Service No: ED 389 378). 